片状金属粉とガスアトマイズ水素吸蔵合金粉を用いた高密度水素吸蔵電極

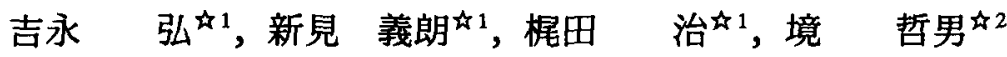 \\ 41 福田金属箔粉工業(侏)，广 607-8305 京都市山科区西野山中臣町 20. \\ 42 大阪工業技術研究所, $7563-8577$ 池田市緑丘 1-8-31.
}

\title{
Highly Densed-MH Electrode Using Flaky Metal Powder and Gas-atomized Hydrogen Absorbing Alloy Powder
}

\author{
Hiroshi Yoshinaga ${ }^{\star 1}$, Yoshiro Arami ${ }^{\star 1}$, Osamu Kajita ${ }^{\text {*1 }}$ and Tetsuo Sakai ${ }^{\star 2}$ \\ ${ }^{4}$ Fukuda Metal Foil \& Powder Co., Ltd. 20, Nakatomi-cho Nishinoyama Yamashina-Ku, Kyoto 607-8305. \\ ${ }^{* 2}$ Osaka National Research Instiute, AIST, MITI, 1-8-31 Midorigaoka, Ikeda 563-8577.
}

Received December 12, 2000

\section{SYNOPSIS}

Gas-atomizing method was used to fabricate sphere-shaped hydrogen storage alloy powder ( $\mathrm{AB}_{5}$ type alloy). The alloy powder was intermixed with flake-shapes Ni powder, followed by pressure-molding to make electrode. Charge/ discharge cycle test was conducted at current density of $100 \mathrm{~A} / \mathrm{kg}$. The spherical alloy powder was packed densely into the electrode, achieving a maximum capacity per volume of electrode of $1800 \mathrm{Ah} / \mathrm{L}$. The shape effect of the nickel powder and hydrogen storage alloy powder was discussed.

KEY WORDS

flake nickel powder, flake copper powder, gas-atomized hydrogen absorbing alloy, nickel-metal hydride battery

\section{1 緒 蛋}

水素吸蔵合金粉を負極に用いたニッケル水素蓄電池は，高 容量, 高性能であることから携帯電子機器の電源として多量 に使われている．この電池は，有害元素を含まないため環境 適合性に優れ，かつ，エネルギ一密度が高いため，電気自動 車やハイブリット電気自動車(ガソリンエンジンと電気モータ を組み合わせた車)にも使われている.

しかしながら，最近の携帯電子機器や電気自動車の更なる 高性能化，低コスト化の要求を背景に，本電池に対しても製 法のコストダウンが強く求められている.

本研究では，負極に使われる水素吸蔵合金の特性向上はも とより，この材料の潜在能力を最大限に引き出すため粉末の 形状に着目し, 更なる高性能化, コンパクト化及び低コスト 化を目指して，電極に活物質を高充填し高容量を得ることを 試みた。そのためにまず高い充填密度を確保しつつ，しかも， 初期活性化を与える目的で, 球形のガスアトマイズ粉を軽く 粉砕処理した水素吸蔵合金粉を開発し，更にその球形粉の表 面を覆い集電性を向上さすための導電助材として片状金属粉 を新たに開発した。

一方，電極の作製方法に関しても活物質や有機バインダー を水で混練りし集電体に塗布する従来の湿式法に対し，本研
究では，粉末治金的手法による混合，加圧成形で電極を簡単 に作製する方法を開発した．本報ではこれら電極材料及びそ の製法が電極特性の向上並びに低コスト化におよぼす影響に ついて報告する。

\section{2 試料及び実験方法}

\section{1 原料粉の作製}

負極に用いる球形水素吸藏合金粉は，溶融状態の合金から 高圧アルゴンガスガスアトマイスにより直接粉末を造る方法

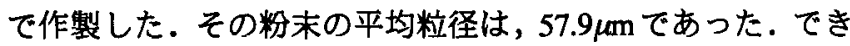
たアトマイズ粉をアルゴンガス中で軽く粉砕した粉末及び不 規則状になるまで粉砕した粉末を作製した。各々の粉末の平 均粒径は $50.9 \mu \mathrm{m}$ と $37.9 \mu \mathrm{m}$ であった. それら粉末の外形，分 析值及び粉末特性を Fig.1 (a,b,c), Table 1, Table 2 に示す.一 方, 導電助材として, 金属粉 (銅, ニッケル)をメカノフュー ション装置(ホソカワミクロン株式会社製)で片状化処理する ことにより，アスペクト比の大きな片状粉を作製した．更に ニッケル粉については673Kでの熱処理による軟質化処理を施 した ${ }^{1-6)}$. その粉末の熱処理による硬度をTable 3に示す. 片状 粉との比較には従来のフィラメント状粉末を用いた。また合 金粉の評価には樹枝状銅粉末を用いた。それらの外形及び粉 
末特性を Fig.2, Table 4 に示す.

2.2 水素吸蔵電極の作製

アトマイズ法で作製した水素吸蔵合金粉の電極材としての 評価は，水素吸蔵合金が充放電に伴う水素の吸蔵放出により 膨張収縮するので, 強固な圧粉体を造るため圧縮性の良い樹 枝状銅粉 Fig.2(c)を用いた. 合金 $1 \mathrm{~g}$ に対して銅粉 $3 \mathrm{~g}$ と混合し $490 \mathrm{MPa}$ で圧粉体を作製し負極とした?).
加圧成形により薄い電極を作製するには, 水素吸蔵合金粉 が球形のため点接触だけでは強度のある圧粉体はできない. そこでプラスチック結着剤としてポリテトラフルオロエチレ ン樹脂(PTFE樹脂)を用いた. 負極を加圧成形法で造る場合, 水素吸蔵合金粉に対して導電助材の配合比を変化させ $(0,5,10$, 20 mass\%) メノー乳鉢で十分混合した．その混合粉に対して 1.0 mass\% の PTFE 樹脂を加えガム状になるまで混練りした.

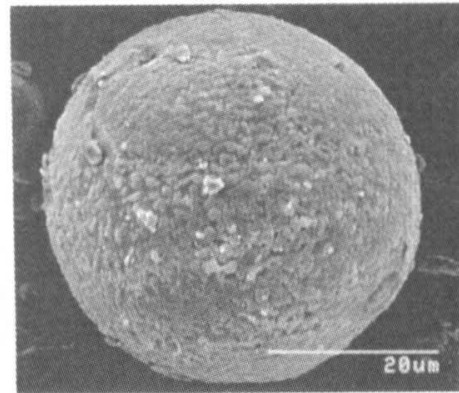

(a) As atomized

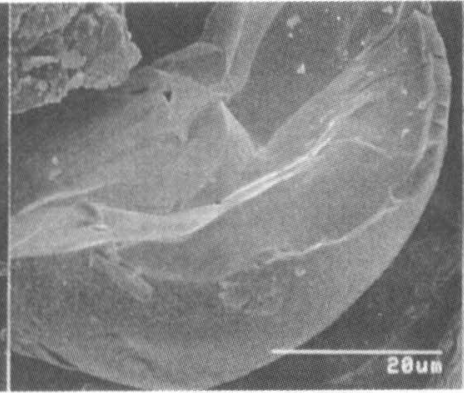

(b) Low ground

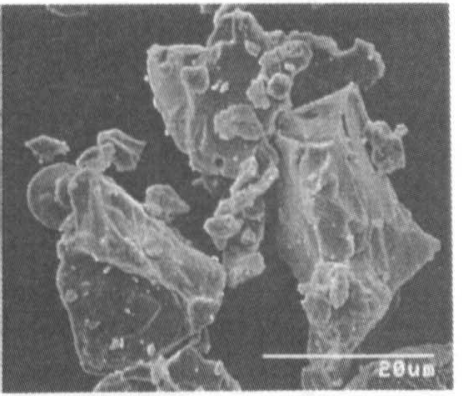

(c) Ground

Fig.1 SEM photographs of hydrogen absorbing alloy powders.

Table 1 Chemical analysis of hydrogen absorbing alloy made of gas atomization method.

\begin{tabular}{|c|c|c|c|c|c|c|c|c|c|c|}
\hline \multicolumn{1}{|c|}{ Chemical Analysis (mass\%) } \\
\hline La & $\mathrm{Ce}$ & $\mathrm{Pr}$ & $\mathrm{Nd}$ & $\mathrm{Ni}$ & $\mathrm{Co}$ & $\mathrm{Mn}$ & $\mathrm{Al}$ & $\mathrm{O}$ & $\mathrm{C}$ & Other \\
\hline 19 & 4.4 & 3.5 & 6.6 & 49 & 9.9 & 4.9 & 2.1 & 0.27 & 0.01 & 0.32 \\
\hline
\end{tabular}

Table 2 Properties of hydrogen absorbing alloy powder produced by gas atomization method.

\begin{tabular}{|c|c|c|c|c|}
\hline \multicolumn{2}{|l|}{ Powder } & As atomized & Low Ground & Ground \\
\hline Particle size & $(\mu \mathrm{m})$ & 57.9 & 50.9 & 37.9 \\
\hline Flow rate & $\mathrm{ec} / 50 \mathrm{~g})$ & 14.7 & 15.0 & Non \\
\hline \multirow{5}{*}{$\begin{array}{l}\text { JIS } \\
\text { Screen analysis } \\
\qquad(\mu \mathrm{m} / \%)\end{array}$} & +106 & 1.6 & 0 & 0 \\
\hline & +75 & 2.2 & 0 & 0 \\
\hline & +63 & 13.2 & 14.0 & 2.2 \\
\hline & +45 & 21.1 & 23.8 & 11.1 \\
\hline & -45 & 61.9 & 62.2 & 86.7 \\
\hline \multicolumn{2}{|c|}{ Apparent density $\left(\mathrm{g} / \mathrm{cm}^{3}\right)$} & 4.10 & 4.00 & 3.11 \\
\hline Tap density & $\left(\mathrm{g} / \mathrm{cm}^{3}\right)$ & 5.00 & 4.95 & 4.54 \\
\hline Green density * & $\left(\mathrm{g} / \mathrm{cm}^{3}\right)$ & 6.53 & 6.50 & 6.15 \\
\hline
\end{tabular}

$*$ : Test piece : $16 \phi, 1 \mathrm{~g}$ Compacting pressure : 490MPa Binder/Lubricant : $1.0 \%$, PTFE 
Table 3 Vickers hardness of flake nickel powders heat-treated at Ar gas.

\begin{tabular}{c|c}
\hline & Ni Flake \\
\hline As milled & $344 \mathrm{HV}$ \\
\hline $673 \mathrm{~K}$ & $111 \mathrm{HV}$ \\
\hline
\end{tabular}

Heat-treating in $\mathrm{Ar}, 0.5 \mathrm{~h}$

MVK-H300 : Akashi Co.,Ltd.
そのガム状物をロールでシート状にし, $1.0 \mathrm{~g}$ を切り出し, 直 径 $16 \mathrm{~mm}$ の金型に入れ所定の成形圧力を加えペレットを作製 した.比較材料も同様な方法でペレットを作製し負極とした. 2.3 充放電試験

水素吸蔵合金粉, 金属粉末 (導電助材)及びPTFE樹脂を加圧 成形して造ったペレットをニッケル金網(線径 $0.06 \mathrm{~mm}, 150 \mathrm{mesh})$ で挟み, 周囲をスポット溶接して, ポリプロピレン不織布で 包み負極とした. 正極には，既製の焼結式ニッケル極を配し た. 電解液には $6 \mathrm{M} \mathrm{KOH}$ を用いて負極規制の開放型セルを

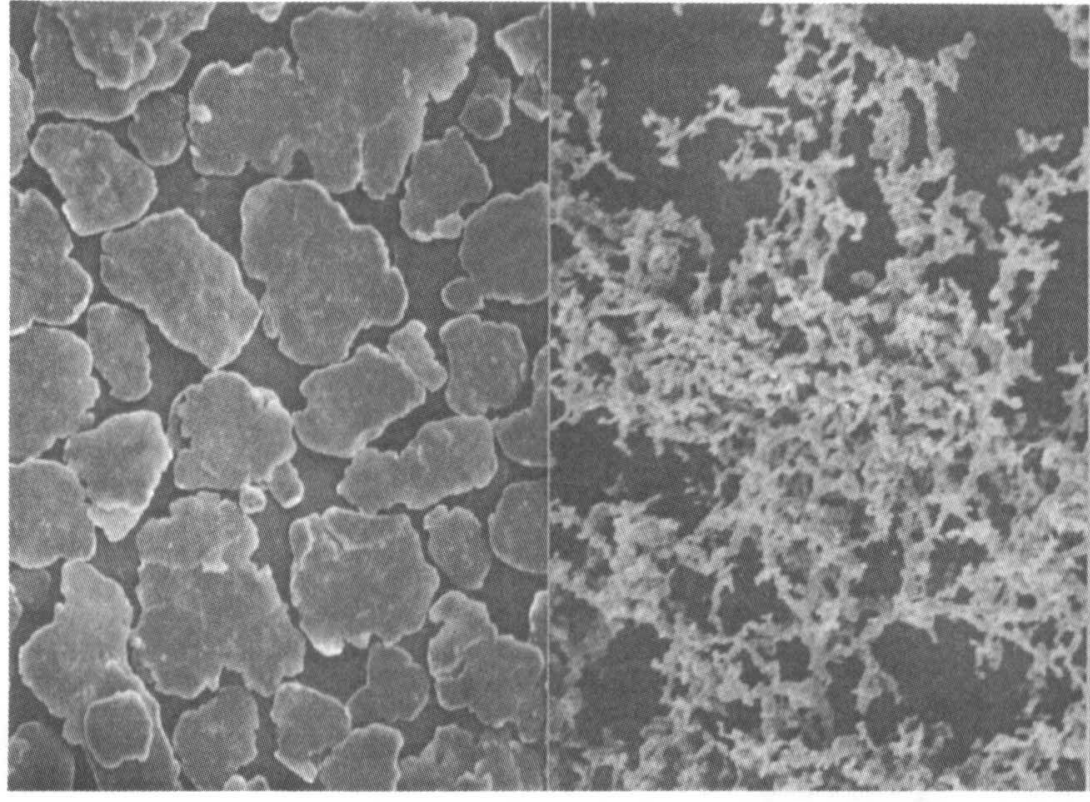

(a) Flake nickel (b) Filamentary nickel

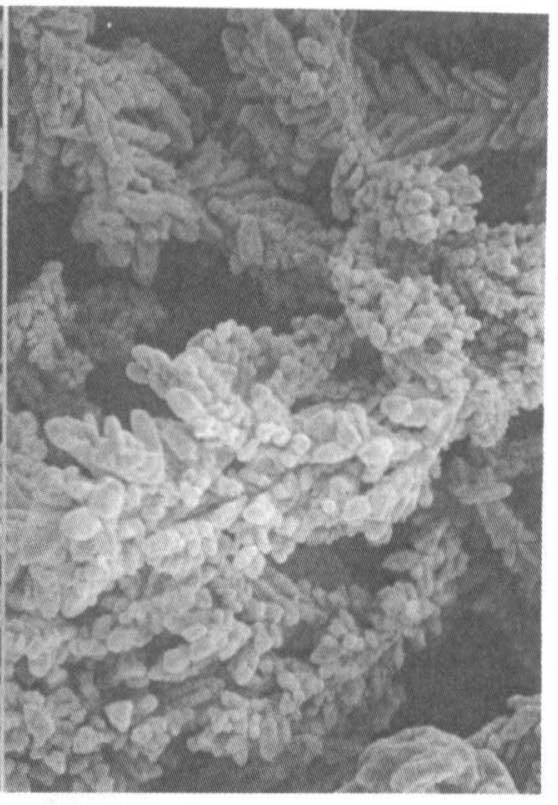

(c) Dendritic copper

$20 \mu \mathrm{m}$

Fig.2 SEM photographs of some conduction-assisting metal powders.

Table 4 Properties of various conductive metal powders.

\begin{tabular}{|lc|l|c|c|}
\hline \multicolumn{2}{|l|}{ powder } & \multicolumn{2}{|c|}{ Nickel } & Copper \\
\hline Particle shape & Flake & Filamentary & Dendritic \\
\hline Particle size $\quad(\mu \mathrm{m})$ & 11.0 & $1.0 * 1)$ & $2.3 * 1)$ \\
\hline \multicolumn{2}{|l|}{ Specific surface area $\left(\mathrm{cm}^{2} / \mathrm{g}\right)$} & 19000 & 8000 & 5100 \\
\hline Apparent density $\quad\left(\mathrm{g} / \mathrm{cm}^{3}\right)$ & 0.9 & 0.8 & 0.9 \\
\hline Tap density $\quad\left(\mathrm{g} / \mathrm{cm}^{3}\right)$ & 2.47 & 0.41 & 1.69 \\
\hline Green density *2) & $\left(\mathrm{g} / \mathrm{cm}^{3}\right)$ & 7.13 & 5.46 & 6.82 \\
\hline
\end{tabular}

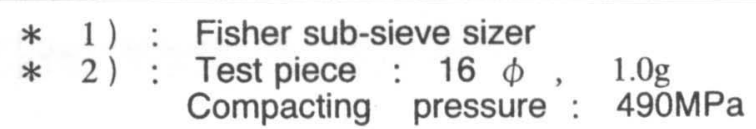




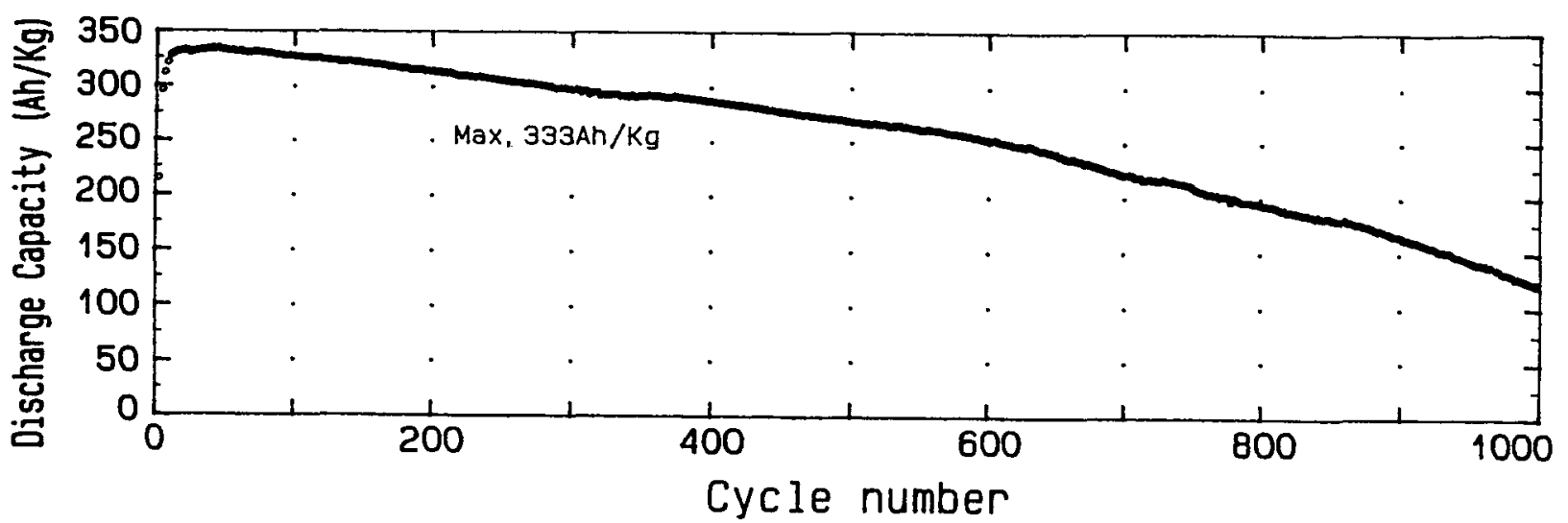

Fig.3 Discharge capacity vs. cycle number curves for metal hydride electrodes made of gas atomized powders.

造った. 試験条件は, $100 \mathrm{~A} / \mathrm{kg}$ で $4 \mathrm{~h}$ 充電し, $0.5 \mathrm{~h}$ 充電休止し, $100 \mathrm{~A} / \mathrm{kg}$ の電流で終止電圧 $0.8 \mathrm{~V}$ まで放電させるサイクルを繰 り返した.測定温度は293Kで行った。比較粉末も同様な方法 で試験した。

\section{3 実験結果及び考察}

3.1 水素吸蔵合金粉の電極としての評価

ガスアトマイズ法で作製した球形水素吸蔵合金粉の負極と しての放電容量とサイクル特性を調べた結果を Fig.3に示す. 初期活性化が遅く，最大放電容量 (333 Ah $/ \mathrm{kg})$ に達するサイク ル数が 40 サイクルと多いが，500サイクルにおいて最大放電 容量の $85 \%$ を維持していた.

一般にはガスアトマイズ法で作製した粉末は粒子表面が酸 化されていて，初期活性化が遅いとされている。，その対策と して高濃度のアルカリ溶液中で劣沸する方法が提案されてい るが，粉末製造工程が増え廃液の環境への影響もある。本研 究ではアトマイズ粉をアルゴンガス中で軽く粉砕し, 粒子の 一部分に新鮮な破断面を出した粉末を造った. 更に $63 \mu \mathrm{m}$ 以下 に粉砕した不規則形状粉末を造り，粉末の形状と粓子表面状 態が初期活性化や放電容量, サイクル寿命に与える影響を調 べた.その結果をFig.4(A,B，C)に示す.アトマイズ粉を用いた 電極 (A)は，初期活性化が一番遅く最大放電容量 $(333 \mathrm{Ah} / \mathrm{Kg})$ に達するサイクル数(40サイクル)も非常に多かった.アトマ イズ粉をアルゴンガス中で軽く粉砕し，粒子の一部分に新鮮 な破断面を出した粉末を用いた電極(B)では，初期活性化も早 く, 最大放電容量 $(333 \mathrm{Ah} / \mathrm{Kg})$ に達するサイクル数も 15 サイ

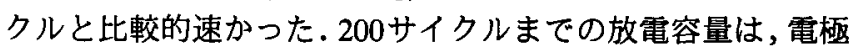
(A)とほとんど同じ值を示した.この結果より合金粒子の一部 に新生面を造るとサイクル初期から高い放電容量が得られる ことが分かった. 一方, アトマイズ粉をアルゴンガス中で $63 \mu \mathrm{m}$ 以下に粉砝し粒子に新鮮面と破断面を多く出した粉末を 用いた電極 $(\mathrm{C})$ では, 初期活性化が最も早く, 最大放電容量 $(337 \mathrm{Ah} / \mathrm{Kg})$ もそれに達するサイクル数も10サイクルと非常に 速かった.しかし，160サイクルを過きる辺りから放電容量が 大きく減少した.これは，合金が水素の吸蔵放出を絽り返す

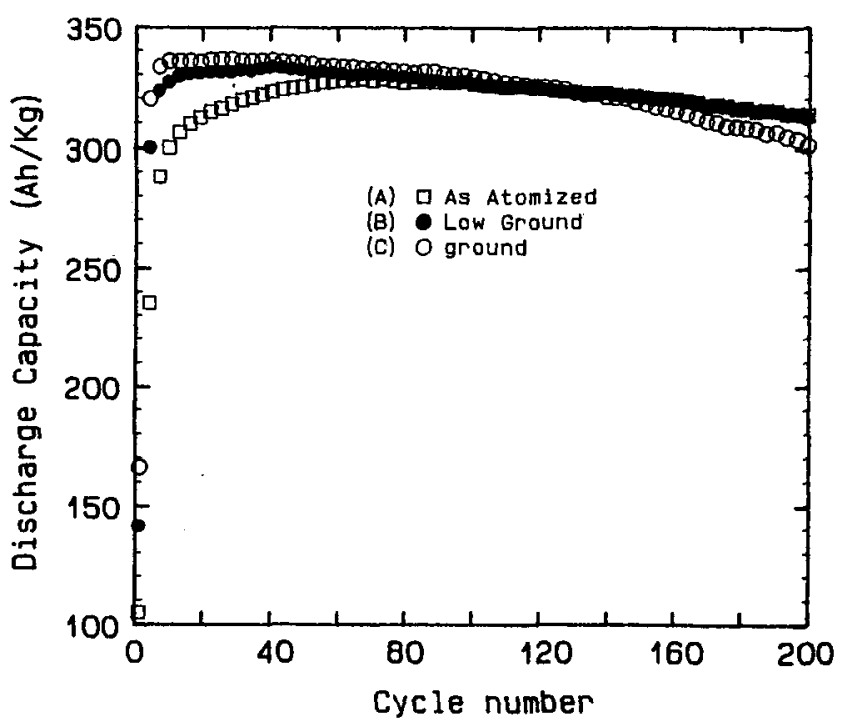

Fig.4 Discharge capacity vs. cycle number curves for metal hydride electrodes prepared under various crushing.

ことにより徐々に微粉末となり合金粒子間の接点が多く接触 抵抗が增大したものと考えられる。

3.2 水素吸藏合金の形状と各種密度

負極の活物質として用いる水素吸蔵合金の粒子形状が電極 への充填量に与える影響を調べるため，粉末の見掛密度， タップ密度及び圧粉密度について試験した結果を Fig.5に示 す. 従来は，所定の合金成分を溶解，鋳造後，その塊を機械 的に粉砕し分級して水素吸蔵合金粉を製造している，活性金 属の粉末は粉歴爆発の危険を伴うので，粉末の製造はアルゴ ン雾囲気中で行う．この方法による粉末の形状は不規則形粉 である．そのため富密度が低くい，密度の比較に用いる不規 則形状粉末は，アトマイズ合金を粉砕した粉末を用いた。こ れに対してガスアトマイズ法で作製した球形水素吸藏合金粉 や軽く粉砕したアトマイス合金粉は，見掛密度，タップ密度 及び圧粉密度において，アトマイズ粉を粉砕して造った不規 則形粉よりも大きい值を示した. ガスアトマイズ法で造った 粉末は，ガスアトマイス特有の球形であり，一定体積中に真 
密度の $60 \%$ 以上の粉末が充填された結果である.ただし，水 素吸蔵合金が球形粉末であるため, 成形体ができない。そこ で，圧粉密度測定には PTFE 樹脂 1.0 mass\%を加えた。

3.3 結着剤の選択

球形粉末を用いて薄い圧粉体を造ることは粉末が球形のた めに点による接点となり高い成形圧力を加えても圧粉体の強 度が弱い。したがって，結着剂を用いて強度を補強すること を試みた.プラスチック結着剤は, 導電性がないに等しいた め, 水素吸蔵合金粉とニッケル粉の間や粉末同士の電気伝導 性を阻害し負極の放電特性が悪くなることが予想される．そ こで, 電極用結着剤としての良好な樹脂を選ぶため, PTFE樹 脂やカルボキシメチルセルロース樹脂(CMC樹脂)を用い電極 を作製し充放電試験をした結果を Fig.6に示す. PTFE樹脂を 用いて作製した電極は, $\mathrm{CMC}$ 樹脂を用いて作製した電極より 高い放電容量を示した. PTFE樹脂は結着剤として, ほかに粒 子同土や金型の壁との滑りを良くし密に充填さす潤滑剤の役 割を持つことが分かった．その潤滑効果により圧粉密度が大 きくなり，体積当たりの放電容量が大きくなった．樹脂の添

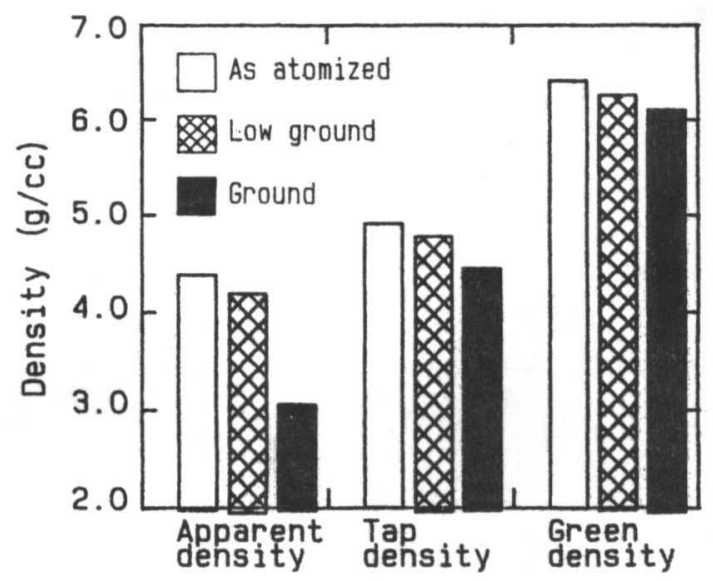

Fig.5 Density of hydrogen absorbing alloy powders.

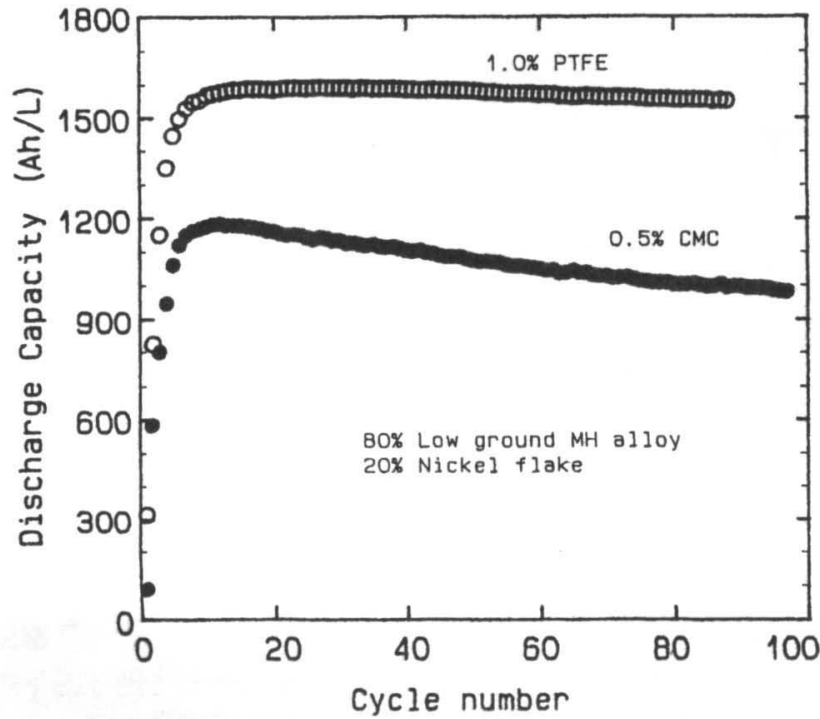

Fig.6 Discharge capacity vs. cycle number curves for metal hydride electrodes made with various resin binder.
加量としては，1.0 mass\% が電極作製や放電容量において良 かった. CMC樹脂を用いた電極は, 電極シートの作製が困難 で放電容量も低かった。

\section{4 金属粉の形状効果}

導電助材として用いるアスペクト比が大きな片状銅粉及び 片状ニッケル粉は，メカノフュージョン装置で作製した ${ }^{1-6)}$. 片状ニッケル粉は合金との接触を強固にするためアルゴンガ ス中 $673 \mathrm{~K} て ゙$ 熱処理した粉末 (硬度 $111 \mathrm{HV}$ )を用いた ${ }^{3-6)}$. 比較 には従来のフイラメント状ニッケル粉を用いた。

片状ニッケル粉と球形水素吸蔵合金粉を混合したとき合金 表面がどのような状態であるかを SEM で観察した結果を Fig.7に示す. 片状ニッケル粒子は, その形状異方性と比表面 積が大きいことから球形水素吸蔵合金粒子の表面を面接触し て覆っている. その結果，混合粉は，球形状態である。この ように片状粉やフイラメント状粉と混合した粉末が加圧力に より圧粉密度が変化する様子を Fig.8に示す.

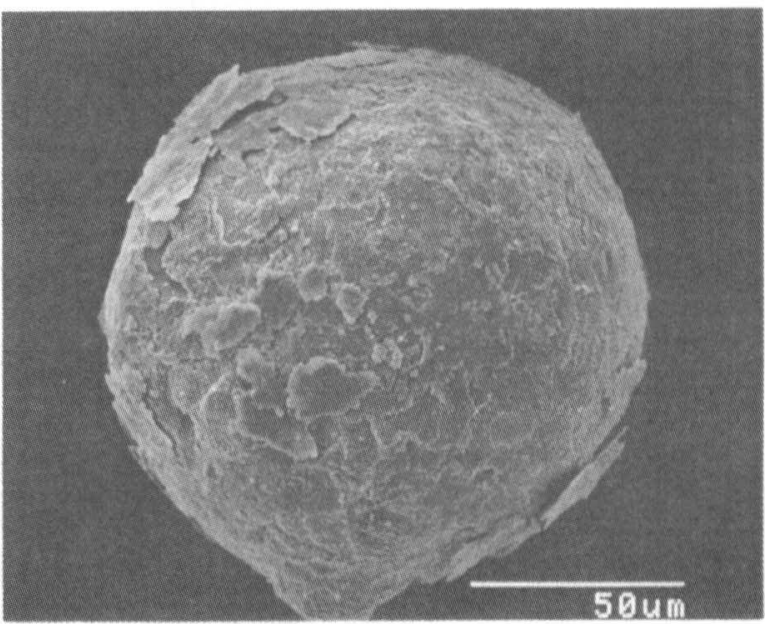

Fig.7 SEM photographs of hydrogen storage alloy powder was intermixed with flake-shapes $\mathrm{Ni}$ powder.

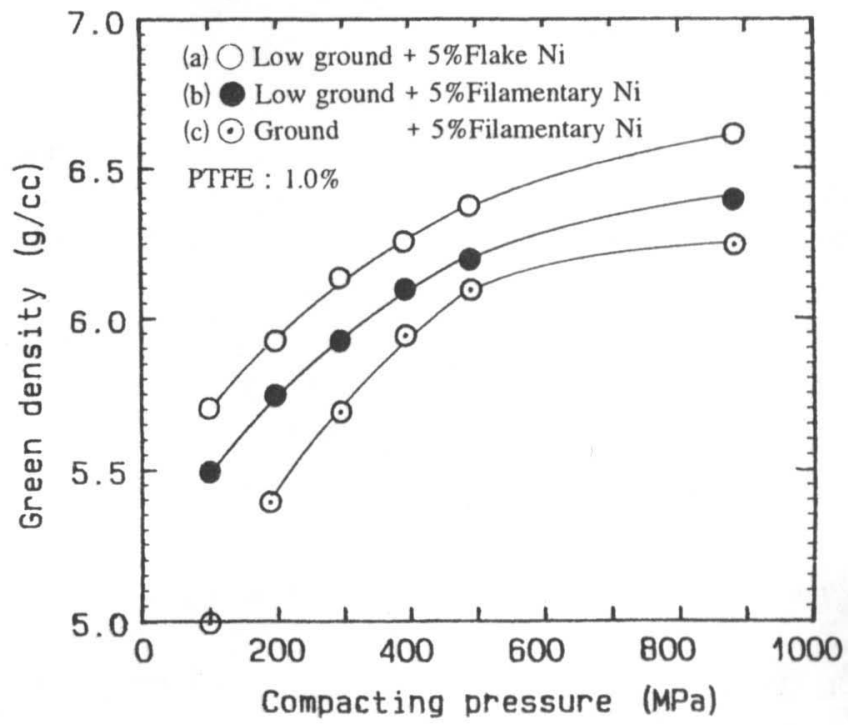

Fig.8 Green density of a green compact made of various compacting pressure. 


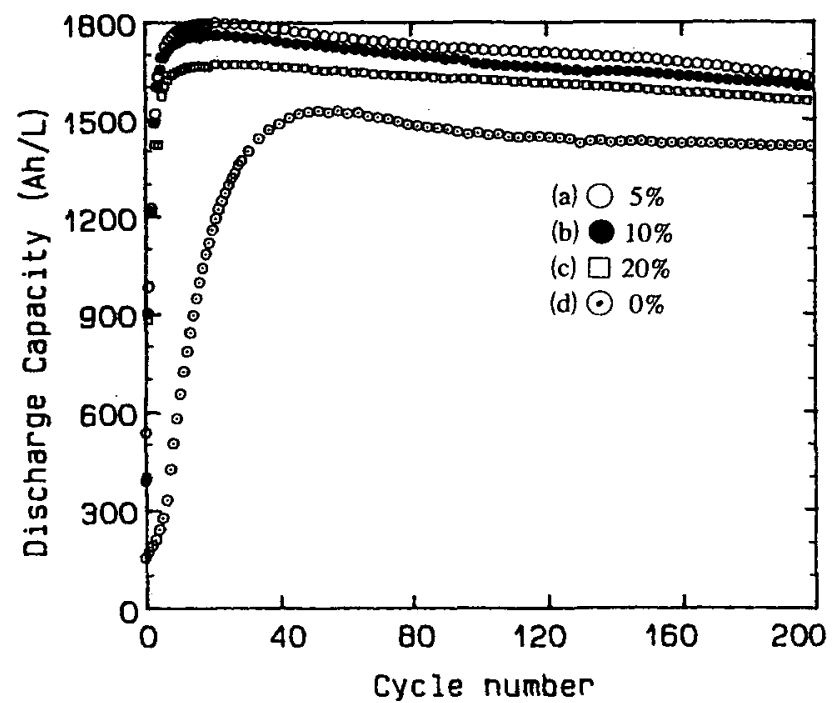

Fig.9 Discharge capacity vs. cycle number curves for metal hydride electrodes made of various amount of flaky nickel powder.

片状ニッケル粉と軽く粉砕したアトマイズ合金粉を混合し た粉末の圧粉密度は, 粉末全体が球形のため大きな值を示し た. その結果, 負極に多くの水素吸蔵合金粉が充填され，よ り多くの水素を蓄積できるため放電容量が向上することが推 察された。一方，フイラメント状粉末と不規則形状水素吸藏 合金粉を混合した粉末は，詰まりが悪く圧粉密度は片状ニッ ケル粉と球形水素吸蔵合金粉を混合した粉末より小さい值を 示した.このことは，片状ニッケル粉と軽く粉砕したアトマ イズ合金粉を用いると，体積当たり多くの活物質が充填され 放電容量が大きくなることが予想される。

電池には,多くの活物質を充填するほど高性能が得られる. 一方，導電助材を多く添加すると集電性が向上して質量当た りの容量が高いが, 体積当たりの容量は少なくなる.そこで, 水素吸蔵合金粉に対して導電助材の配合比を変化 $(0,5,10,20$ mass\%)させたとき, 体積当たりの放電容量に与える影響を調 ベるために放電容量とサイクル数を調べその結果をFig.9(a〜d) に示す.軽く粉砕したアトマイズ合金だけで作製した電極(d) は，初期活性化が非常に遅く最大放電容量 $(1540 \mathrm{Ah} / \mathrm{L})$ に達す るのに50サイクルを要した. その後放電容量は, やや減少す るが 90 サイクルから 200 サイクルまでは $1420 \mathrm{Ah} / \mathrm{L}$ と一定の 值を示した. 片状ニッケル粉を 20\%添加した電極(c)は, 初期 活性化は (a) 電極より速く最大放電容量に達するのに 10 サイ クルであった. その後放電容量の減少は $5 \%$ と少なく 200 サイ クルでは $1560 \mathrm{Ah} / \mathrm{L}$ となった. 片状ニッケル粉を $5,10 \%$ 添加 した電極 (a,b)の初期活性值は 520,380Ah/L と高く, 初期活性 化は電極 (c)よりやや遅く, 最大放電容量 $(1808,1740 \mathrm{Ah} / \mathrm{L})$ に 達するのに 15,12 サイクルかかった. 導電助材としてての片状 金属粉の添加は必要であることが分かった．また添加量は， 5\%で最大の放電容量を示した。

次に水素吸蔵合金粉や導電助材 $(\mathrm{Ni}, \mathrm{Cu})$ の形状が体積当たり の放電容量に与える影響を調へたた結果を Fig.10に示す. 従来

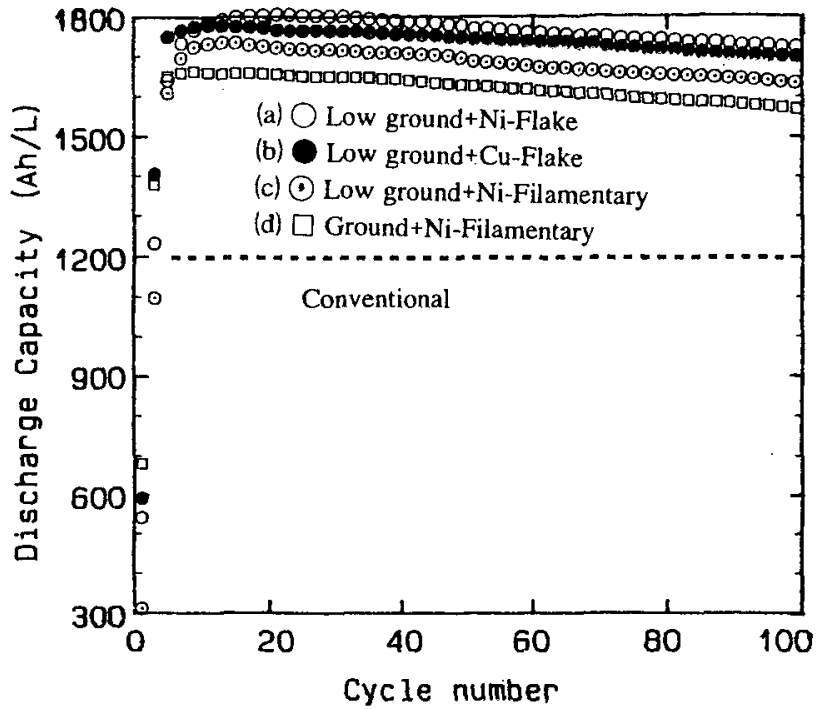

Fig.10 Discharge capacity vs. cycle number curves for metal hydride electrodes made of various additives.

法による放電容量は，概略 $1200 \mathrm{Ah} / \mathrm{L}$ 程度と言われている ${ }^{8)}$. それに対して本研究による粉末治金技術を用いて作製した 負極Fig.9(a〜d)は，いずれも従来法に比べ35\%以上の高い放 電容量を示した。中でも軽く粉砕したアトマイズ合金と片状 金属粉 $(\mathrm{Ni}, \mathrm{Cu})$ 及びPTFE樹脂で作製した負極 $(\mathrm{a}, \mathrm{b})$ が高い放電 容量を示した。これは圧粉密度が大きく活物質が電極容積内 に多く充填されたこと, 片状粉が合金の周囲を少ない量で覆 い集電性を向上させたことによる. 中でも片状ニッケル粉を 用いた電極(a)が一番大きな放電容量 $1808 \mathrm{Ah} / \mathrm{L}$ 示したのは, 熱処理して軟質化した片状ニッヶル粉が，圧粉体を造るとき の加圧力によつて合金粒子と強固に接触したことによる.

\section{5 電極の断面組織}

片状銅粉と球形水素吸蔵合金粉を用いて負極を作製し，そ の充放電テストを 500 サイクル行った後の電極断面組織の SEM写真を Fig.11に示す。球形した合金粒子の内部には，い ずれも割れが形成されており，これらの割れは充放電サイク ル中に生じたものである．この割れにより，電極反応面積が 増大して, 放電容量サイクル特性が向上するものと考えられ た.片状銅粉を用いた電極は 500 サイクル後でも片状銅粉が 球形水素吸蔵合金粒子の周囲を面で接触している. その結果 粒子間の間隙が狭く王粉密度が大きく, 体積当たりの放電容 量が高くなることが分かった.

\section{4 結 雷}

片状金属粉とアトマイス水素吸蔵合金粉を軽く粉砕した粉 末とPTFE樹脂を混練り，加圧成形して造った圧粉体の諸特性 や負極としての電気特性を調べた結果次のようなことが分 かった。

(1) アトマイズ粉をアルゴンガス中で軽く粉砕した粉末と軟質 化した片状ニッケル粉とPTFE樹脂を混合し圧粉体を造る と, 高充填密度になった. 


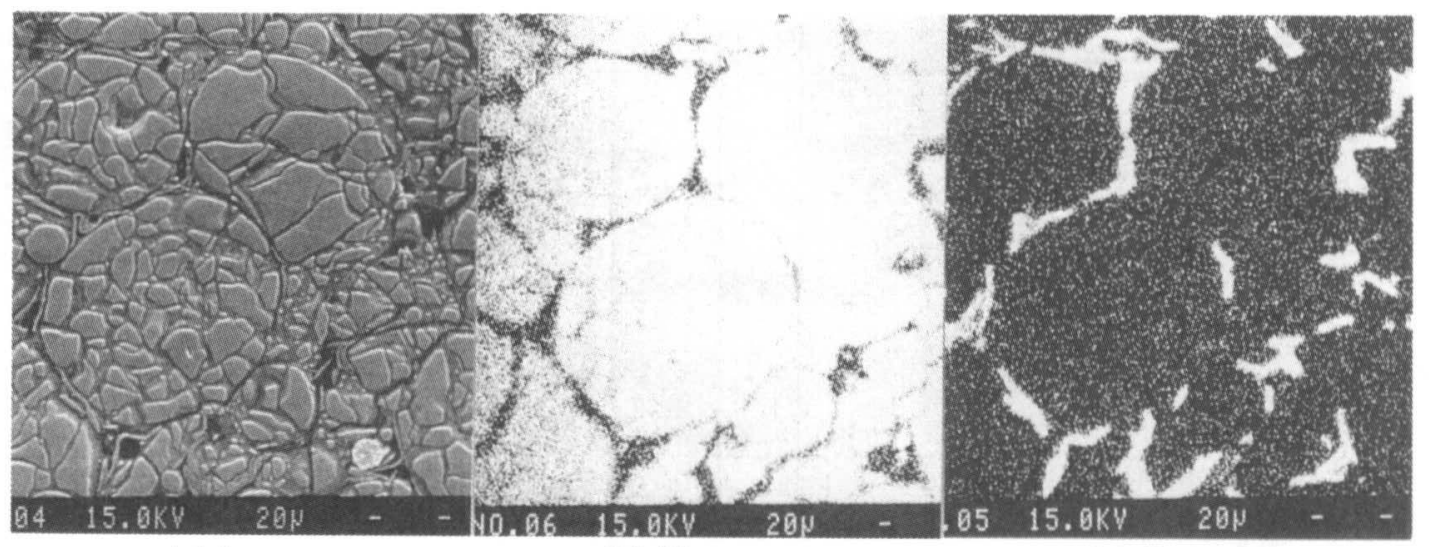

(a) Image

(b) Ni map

(c) Cu map

Fig.11 EPMA image of cross section of metal hydride electrodes with copper powder (after 500 cycles).

(2) アトマイズ粉の粒子の一部に新鮮な破断面を出すことによ り初期活性化が速く, 最大放電容量に達するサイクル数も 速く, サイクル寿命も長い.

(3) 軽く粉研した球形水素吸蔵合金粉と軟質化した片状ニッケ ル粉を用いた負極の放電容量は, 体積当たり $1808 \mathrm{Ah} / \mathrm{L}$ と 従来の $1200 \mathrm{Ah} / \mathrm{L}$ より高い放電容量を示した.

(4) 乾式で混合,加圧成形する簡単な製法でも高容量の負極が できることが分かった.

以上のように, 電極性能向上のため一見単純に見える電極 材料でも, 粒子の形状を変え粉末治金技術を用いて電極を作 製すると充放電特性が向上することが分かった.

\section{文献}

1) 吉永弘, 和田仁, 境哲男, 宮村弘, 栗山信宏, 上原斎: " 片 状銅粉および片状ニッケル粉を用い乾式プレス法により作 製した水素吸蔵電極", DENKI KAGAKU, 63, No.9(1995)847.

2) 吉永弘, 境哲男, 宮村弘, 栗山信宏, 上原斎: 特許第 2726976.
3) H.Yoshinaga, H.Wada, T.Sakai, M.Miyamura, N.Kuriyama and I.Uehara: "Metal Hydride Electrodes with Lamellar-type Network Structure", J. Alloys Comp., 253-254(1997)665.

4) 吉永弘, 和田仁, 境哲男: " 第 37 回電池討論会要旨集 ", (1996)375.

5) H.Yoshinaga, M.Wada, T.Sakai and I.Uehara: "Electrode for Alkali Secondary Battery and Methode for Producing the Same", U.S Patent 5, 905, 004.

6) 吉永弘, 和田仁, 境哲男: "Ni 水素電池用高性能片状金属粉 とそれを用いた電極作製技術の開発",粉体および粉末治金, 47(2000)61-67.

7) ニッケル・水素電池用水素吸蔵合金の標準化に関する調査 研究報告書: 財団法人大阪科学技術センター付属ニューマ テリアルセンター, ( 平成 5〜10 年).

8) 神田基, 長谷部裕之, 山本雅秋: "ニッケルー水素電池の高 エネルギー密度比", 第274回電池技術委員会講演, 1994年 12 月 2 日. 